2.Выяснение значения путём показа картины, макета, цветового круга:корытодемострация картины,помутилось синее море- показ цветового круга.тесовые воротапоказ картины, царские палаты- показ картины.

4.Объяснение фразеологизмов: белены объелась-означает потерять рассудок. Применим к людям, совершающим глупости, несуразности, дурное; была б на посылках-выполнять чужие поручения.

5.Использование толкового словаря: землянка-углублённое в землю жилище, прямоугольное или округлое в плане, с перекрытием из жердей или брёвен, засыпанных землёй.Кичка — старинный праздничный головной убор замужней женщины.

Благодаря чтению внутренний мир ребенка становится более эмоциональным, развивается воображение. Поэтому если на уроке во время изучения нового произведения стараться объяснять значение незнакомых для детей слов, то детям будет понятнее смысл, станет интереснее произведение, будет обогащение словарного запаса. $* * *$

1. Яковлева, Т.В. Этнокультуроведческий подход в обучении родному языку в начальной школе / Т.В. Яковлева, В.В. Демичева ;БелГУ // Начальная школа. - 2006. - №11.-С. 65-70.

2. Универсальный словарь школьника: 1-4 классы.- Москва:Эксмо,2015.- 480с.- (Светлячок).

3. Ожегов С. И. Толковый словарь русского языка. М.: Мир и Образование, 2014. 1376 с.

\title{
Крапивина В.C. \\ Колористические способности как психолого-педагогическая категория и специфика их развития
}

Омский государственный педагогический университет, Факультет искусств, кафедра изобразительного искусства и методики его преподавания

(Россия, Омск)

doi: $10.18411 / l j-31-10-2017-45$

idsp: 000001:lj-31-10-2017-45

\section{Аннотация}

В данной статье охарактеризованы колористические способности как психологопедагогическая категория, представлена классификация способностей, выявлены педагогические условия развития колористических способностей.

Ключевые слова: общие и специальные способности, художественно-творческие способности, колористические способности, педагогические условия

Повышенное внимание к проблемам колористических способностей и специфики их развития прослеживается в современной художественно-педагогической литературе. Колористические способности учащихся можно назвать важным средством формирования живописной грамотности.

В.А. Крутецкий характеризует способности как прижизненные образования, индивидуально-психологические особенности человека, отвечающие требованиям конкретной деятельности и являющиеся условием ее успешного выполнения. Наиболее распространенную классификацию способностей предложил С.Л. Рубинштейн, автор поделил их на общие и специальные. Общие - совокупность всех качеств человека, а именно эмоциональной сферы, интеллекта, темперамента, темпа деятельности, тонуса, которые влияют на продуктивность деятельности. Специальные - способности, 
проявляющиеся в конкретном виде деятельности. Представим колористические способности в общей классификации способностей в виде схемы.

Колористические способности в общей классификации способностей

Л.А. Ивахнова определяет художественно-изобразительные способности как систему врожденных и выработанных операционных качеств, которые обеспечивают успешное художественное творчество. Л.Б. Ермолаева-Томина, характеризует способности к художественной деятельности как человеческие способности творить в искусстве личность, а не отдельно отработанные профессиональные навыки. Различные колористические способности могут относится и к художественным и к творческим.

Выявим условия развития колористических способностей в процессе обучения. Под педагогическими условиями понимается совокупность внешних и внутренних обстоятельств, от выполнения которых зависит результат развития. Первое условие - это побуждение адаптационного рефлекса. Оно заключается в том, что учащиеся ориентируются в своей деятельности на требования педагога. Если педагог в свою очередь направляет учащихся на самостоятельный поиск творческого решения проблемы, то учащийся подстраивается под него. В процессе развития колористических способностей не следует давать четкого алгоритма решения. Второе условие необходимость одновременного развития изобразительных и творческих навыков. Отработка выразительных возможностей цвета, возможна на коротких заданиях, упражнениях. Творческие навыки необходимо развивать на абстрактном материале, в процессе выполнения нестандартных заданий. Третье условие формирование способностей к художественно-творческой деятельности - принцип дифференциации и интеграции. Сама природа творчества определяется нестандартным соединением разных элементов. Поэтому построение способностей к творчеству рекомендуемся на развитии обслуживающих его психических процессов. К ним можно отнести - восприятие, память, мышление, воображение.

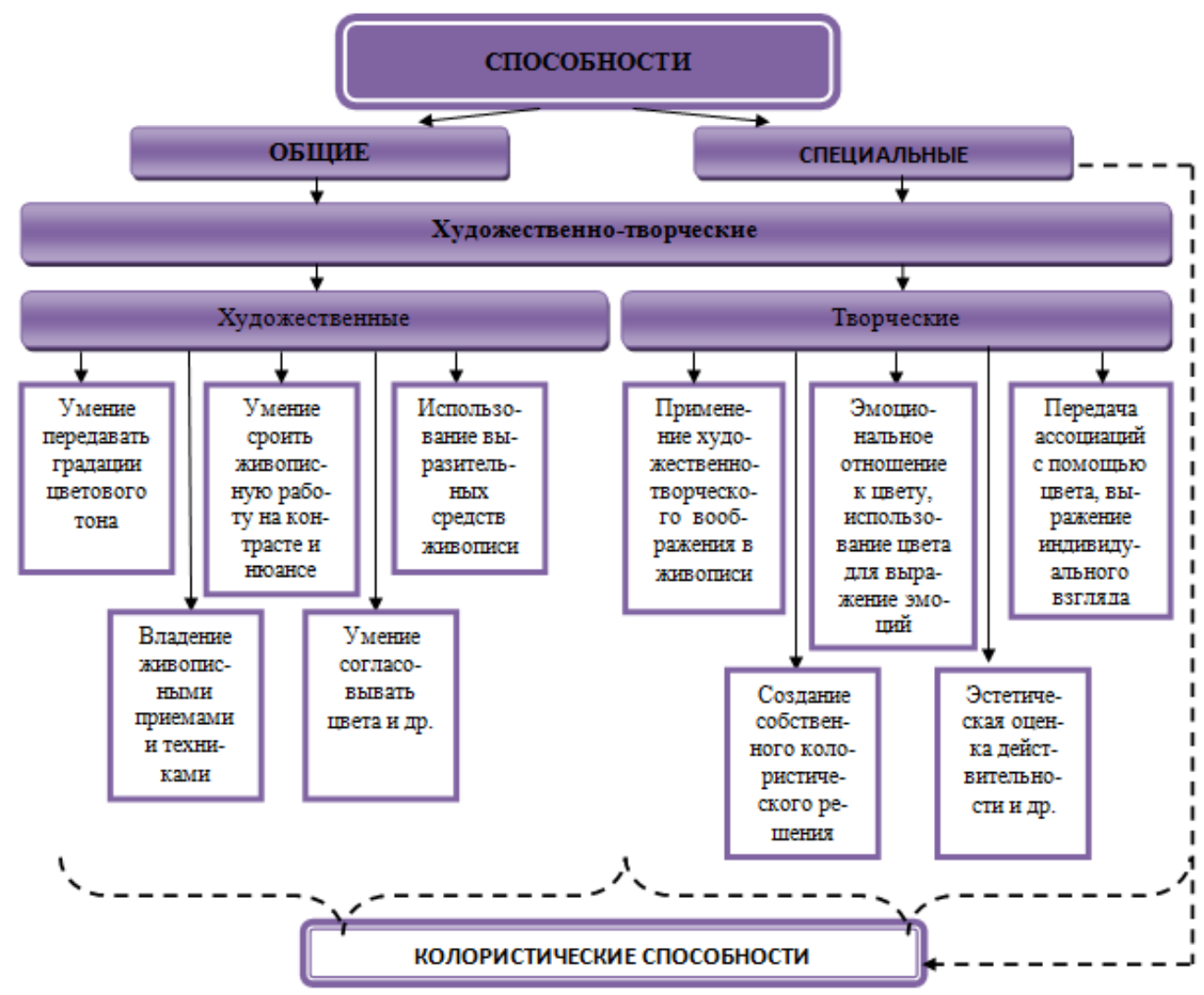


В заключении следует отметить, что колористические способности как психологопедагогическая категория представляют собой одну из составляющих художественнотворческих способностей, развитие которых является сложным процессом, требующим определенных педагогических условий.

$$
* * *
$$

1. Ермолаева-Томина, Л.Б. Психология художественного творчества учебное пособие для вузов / Ермолаева-Томина Л.Б. - М.: Академический Проект, Культура, 2015. - 304 с.

2. Ивахнова, Л.А. Профессиональная деятельность учителя изобразительного искусства: учебное пособие. - 3-е изд., перераб. и доп. / Л.А. Ивахнова. - Омск: Изд-во ОмГПУ, 2013. - 116 с.

3. Рубинштейн, С.Л. Основы общей психологии: учеб. пособие для студентов высших учебных заведений / С.Л. Рубинштейн. - СПб.: Питер, 2007. - 713 с.

\section{Кукса Д.А., Кукса П.В. \\ Некоторые учебно-познавательные трудности иностранных военнослужащих в процессе адаптации к обучению в российском вузе}

РВВДКУ имени В.Ф. Маргелова

(Россия, Рязань)

doi: $10.18411 / l j-31-10-2017-46$

idsp: 000001:lj-31-10-2017-46

С каждым годом все больше иностранных граждан прибывает в Россию для получения высшего образования, и каждый иностранный обучаемый объективно проходит процесс адаптации. Термин «адаптация» в современной науке имеет ряд толкований.

Мы вслед за авторами «Большого психологического словаря» придерживаемся следующего определения термина: «адаптация - приспособление человека как личности к существованию в обществе в соответствии с требованиями этого общества и с собственными потребностями, мотивами и интересами».

Иностранные военнослужащие, обучающиеся на специальном факультете РВВДКУ, являются представителями различных этнических групп и культур, имеют национально-психологические и индивидуальные особенности, неодинаковый уровень базовой подготовки. Это обусловливает специфику процесса их обучения на всех этапах и определяет актуальность решения проблемы социально-психологической адаптации в целом и адаптации к учебному процессу в частности.

В процессе обучения иностранные военнослужащие испытывают учебнопознавательные трудности, вызванные различными факторами, в первую очередь:

- языковым барьером;

- преодолением различий в системах образования;

- организацией учебного процесса, отличного от формы и методов организации на родине;

- новыми требованиями в системе контроля знаний;

- формированием навыков самостоятельной работы;

- информационной насыщенностью учебных занятий;

- бытовыми условиями;

- погодными (климатическими) условиями;

- коммуникативными трудностями в процессе межличностного общения внутри многонациональной группы, общения с преподавателями и офицерами и т.д. 